\title{
Imaging of the Relationship Between Eating Habits of Parents of Preschool Children and Patterns of Children's Consumption of Fast-food Type Products With the Use of Correspondence Analysis Methods
}

\author{
Marta Stachurska ${ }^{1,2}$, Rafał Milewski ${ }^{3}$, Sylwia Dzięgielewska ${ }^{2}$, \\ Anna Justyna Milewska ${ }^{4}$
}

1 Student Scientific Group at the Department of Statistics and Medical Informatics, Medical University of Bialystok, Poland

2 Public Health Student, Medical University of Bialystok, Poland

3 Nursing Student, Medical University of Bialystok, Poland

4 Department of Statistics and Medical Informatics, Medical University of Bialystok, Poland

\begin{abstract}
Health behaviours of preschool children have a considerable impact on the shaping of habits later on in their lives. Parents' and guardians' role is to develop positive health patterns and represent exemplary models to be followed by children. The aim of the paper is to present the use of correspondence analysis for the assessment of the relationship between eating habits of parents and children, as well as for the determination of the most common situations in which preschool children consume fast-food products and to find the relationship between the frequency of fast-food consumption and BMI values in preschool children. The tests were carried out with the use of an own survey carried out in kindergartens in Białystok among parents dropping off and picking up children. 149 correctly filled questionnaires were obtained. The statistical analysis employs the chi-squared test and correspondence analysis. Among the tested children, a statistically significant relationship between body weight and sex was obtained. In the group of children and parents consuming fast-foods, a statistically significant relationship between the frequency of children's and parents' consumption of the products in question was noticed. A statistically significant relationship between the age of introduction of fast-food products into the child's diet and their BMI was found. A situation that was statistically significant as far as contribution to frequent consumption of fast-food products by children, i.e. at least once a week (as compared to sporadic), were children and parents shopping together. The relationship between the frequency of fast-food consumption by parents and children was presented in the form of correspondence maps, as well as the relationship between the child's BMI and the age when the first fast-food product is served, and the relationship between the child's BMI and the frequency of their consumption of fast-foods. Unfortunately, despite the high awareness among parents of the harmful effects of fast-food products and the widespread health education programmes, a number of the children in kindergartens were overweight or even obese. For this reason,
\end{abstract}


the quality of the educational programmes in kindergartens, as well as in various media outlets, needs to be improved, with emphasis put on their effectiveness, in order to minimise the problem of the occurrence of overweight and obesity in children. It is also important for parents rearing children to pay special attention not only to their children's menus, but also to foods consumed in the presence of children.

\section{Introduction}

Eating habits are the basic element of a healthy lifestyle of preschool and school children. Childhood is the most appropriate period to shape it correctly. Among the factors that play an important role in children's diets there are the eating habits of parents or guardians, food advertising, nutritional habits, and the level of nutritional education (KoziołKozakowska et al., 2007; Sosnowska-Bielicz \& Wrótniak, 2013). According to some authors, the influence of nutritional behaviours of small children and mimicking the habits of adults is greater than that of advertising (Kraak \& Pelletier, 1998). Due to time constraints, parents prefer to serve their children fast, ready-made meals rather than dinners containing a considerable quantity of nutritious ingredients with no fat, sugars, or preservatives added. Children are frequently taken to McDonald's type restaurants to consume hamburgers or chips (French fries) (Łoś-Rycharska \& Niecławska, 2010). The term "fast-food" refers to food products such as hamburgers, fried chicken strips, chips (French fries), drinks with a high fat content (e.g. fruit or milk cocktails), or sweet drinks served in international franchises. These are highly calorific per a small portion (high-energy foods) (Gheribi, 2014; Rosenheck, 2008).

The problem of overweight and obesity is becoming increasingly pronounced both in rich and developing countries. The increased incidence of this phenomenon in children may have disastrous consequences for the psychophysical development of the young generation and cause numerous diseases in adulthood (Marcysiak, 2009). Overweight and obesity are currently the most serious threat to public health both in Poland and abroad. The main factors that are conductive to the development of the disease are bad eating habits and lack of physical activity. In the WHO European Region, overweight is the most common childhood health problem. Currently, approx. $20 \%$ of children have excess body weight (WHO, Country Office for Poland, 2006). Among the most common measures of body weight is the BMI (Body Mass Index), calculated as the quotient of body weight (in kilograms) and the square of its height (in meters). According to the 
World Health Organization (WHO), BMI for adults is 25 in the case of overweight and 30 in the case of obesity (WHO, 2017). In children and adolescents, BMI interpretation is sex-dependent and changes with age (Centrum Zdrowia Dziecka).

The aim of this paper is to present the use of correspondence analysis for the assessment of the relationship between nutritional behaviours of parents and children, as well as for the determination of the most common situations in which preschool children consume fast-food products and to find the relationship between the frequency of fast-food consumption and BMI values in preschool children.

\section{Materials and Methods}

The tests were performed with the use of an own survey in four preselected kindergartens in the centre of Białystok in March 2017. 149 correctly filled questionnaires were obtained. The first section contained questions concerning basic information about the parents and children. The next section of the survey was "nutritional behaviour", where the respondents' task was to assess the frequency of fast-food consumption by the child. In this section, real life situations associated with the consumption of such products were to be provided. Then, the age when the child consumed their first fast-food product was to be provided. Moreover, the specific products the child had already been consuming were to be given, as well as the places where fast-food products were purchased and consumed. To increase the reliability of results, the definition of "fast-food type products" was provided at the beginning of this section. Section III of the questionnaire was the basis for the assessment of parents' knowledge about the harmfulness of fast-foods. The task of those surveyed was to indicate the diseases caused by food of this type and provide the BMI formula. The last section of the questionnaire was devoted to parents' attitudes to fast-foods. On the basis of the child's age and the body weight given in the survey, the BMI was calculated and the children were classified as belonging to one of the following groups: underweight, normal, overweight, obese (Centrum Zdrowia Dziecka).

In the statistical analysis, the chi-squared test of independence and Fischer's exact test were used to determine the relationships between qualitative characteristics. Correspondence analysis was used to demonstrate coexistence of characteristics. Results at a level of $\mathrm{p}<0.05$ were considered statistically significant. Statistica 12.0 package by StatSoft was used for the calculations. 
The application of correspondence analysis was dictated by the necessity to present large contingency tables graphically (Jończyk \& Olszewska, 2016; Milewska et al., 2012). Data collected in such tables is usually quite illegible, which makes the assessment of coexistence very difficult. Correspondence analysis belongs to the group of multidimensional exploratory techniques. Graphical presentation of results of analyses is possible by plotting the points reflecting the categories of characteristics on a mostly two-dimensional system of coordinates, possibly minimal loss of information about the real structure of the relationships between them (Greencare \& Hastie, 1987). Interpretation of a map of correspondence consists in the assessment of the position of points that reflect the categories of characteristics on a graph. Such interpretation is also connected with the position of a point in relation to the centre of projection, the position of a point in relation to other points describing categories belonging to the same characteristics, and the position of a point in relation to a point describing the category of another characteristic (Stanimir, 2008). Two points lying close to each other, describing categories belonging to the same characteristic, indicate that these two categories can be merged into one in the contingency table with no adverse impact on the analysis. Points describing categories of different characteristics lying close to each other indicate the existence of relationships between categories, whereas categories do not occur together if the points that reflect them lie on the opposite sides of the projection (Stanimir, 2005).

\section{Results}

In the analysed group, children were brought to kindergartens by women $(74.0 \%)$ more often than by men $(26.0 \%)$. These were mostly persons with a higher level of education $(73.2 \%)$. The median parent age was 35 years $(\min =24, \max =46)$. Among those who granted their consent to participate in the study, the number of parents of boys (51.4\%) was almost equal to the number of parents of girls (48.6\%). The median child age was 5 years $(\min =2, \max =7)$. The median child weight was $19.5 \mathrm{~kg}(\min =12$, $\max =31)$, whereas the median height was $115 \mathrm{~cm}(\min =98, \max =136)$. The median child BMI was 14.9.

Among the surveyed children, a statistically significant relationship between body weight and sex was observed $(\mathrm{p}<0.001)$ - Table 1 . Underweight occurred in girls $(49.2 \%)$ more commonly than in boys $(14.0 \%)$, whereas overweight and obesity occurred in boys (21.1\%) more commonly than in girls $(8.5 \%)$. 
Table 1. BMI distribution for girls and boys

\begin{tabular}{|c|c|c|c|c|}
\hline & underweight & norm & $\begin{array}{c}\text { overweight } \\
\text { or obesity }\end{array}$ & p \\
\cline { 1 - 4 } girls $(\mathrm{n}=59)$ & $29(49.1 \%)$ & $25(42.4 \%)$ & $5(8.5 \%)$ & \multirow{2}{*}{$<0.001$} \\
\cline { 1 - 4 } boys $(\mathrm{n}=57)$ & $8(14.0 \%)$ & $37(64.9 \%)$ & $12(21.1 \%)$ & \\
\hline
\end{tabular}

In the analysed group, only $15.5 \%(\mathrm{n}=23)$ of children had not consumed fast-foods; sporadic consumption was the most common $(71.0 \%, \mathrm{n}=105)$, whereas $13.5 \%$ of children $(\mathrm{n}=20)$ consumed fast-foods at least once a week. The vast majority of parents consuming fast-food products $(90.2 \%, \mathrm{n}=111)$ admitted to eating them in the presence of children.

In the group of children and parents consuming fast-foods, a statistically significant relationship between the frequency of consumption of such products and the frequency of their consumption by parents was observed $(\mathrm{p}<0.001)$. The correspondence between sporadic fast-food consumption by children and parents is the most widespread, present in over $81 \%$ of those surveyed. Frequent consumption, at least once a week, applies to less than $10 \%$ of children and adults (Table 2).

Table 2. Consumption of fast-food products by children and their parents

\begin{tabular}{|c|l|c|c|c|}
\hline \multicolumn{2}{|c|}{ total $\mathrm{n}=122(100.0 \%)$} & \multicolumn{2}{|c|}{ parents } & \multirow{2}{*}{$\mathrm{p}$} \\
\cline { 3 - 4 } & at least once a week & sporadically & \\
\hline \multirow{2}{*}{ children } & at least once a week & $12(9.8 \%)$ & $8(6.6 \%)$ & \multirow{2}{*}{$<0.001$} \\
\cline { 2 - 4 } & sporadically & $3(2.5 \%)$ & $99(81.1 \%)$ & \\
\hline
\end{tabular}

The relationship between the frequency of fast-food consumption by parents and their children is illustrated by the correspondence map - Figure 1. The map shows coexistence of the same frequencies of consumption. If parents ate fast-foods daily, so did the children (the upper-right section of the map); if parents ate fast-foods sporadically, so did the children (points lying on the 0 value of the horizontal axis); similarly, parents who ate fastfoods once or several times a week served them to their children as frequently (the upper-left section of the map).

Parents served their children fast-food products for the first time at a median age of 3.0 years, with the youngest child served fast-food at the age of 1 year. The relationship between child BMI and the age of first serving of a fast-food product is shown on the correspondence map - Figure 2. The co- 


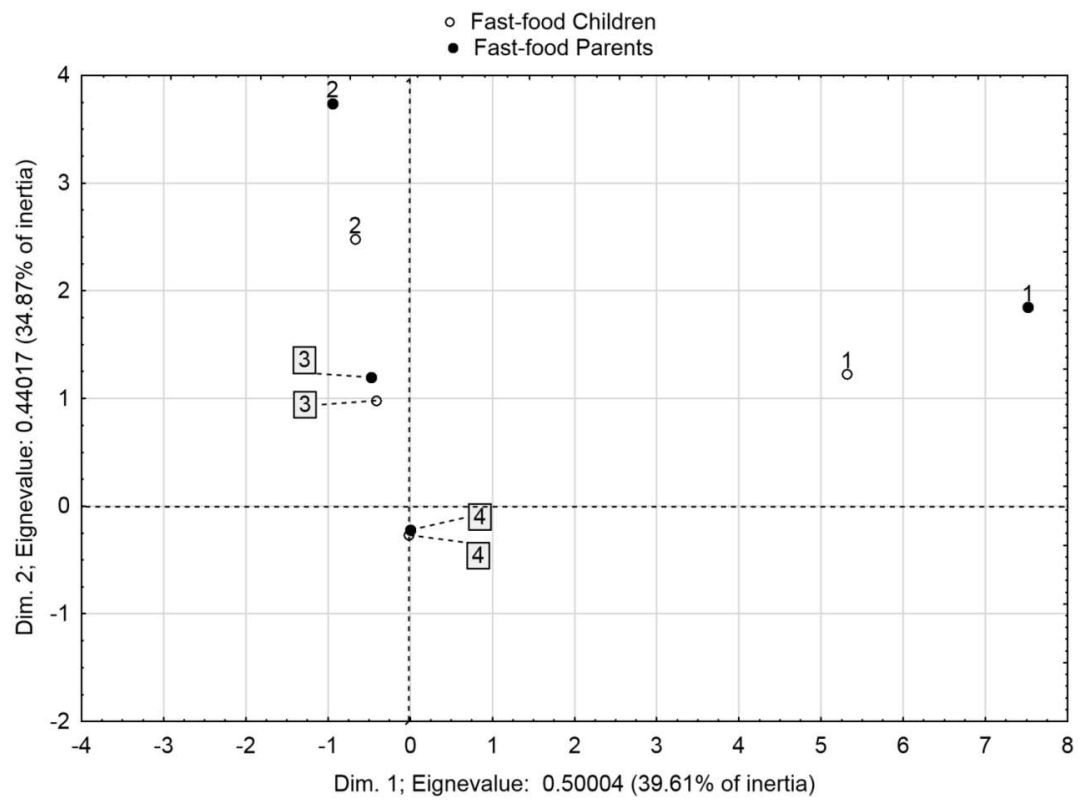

Figure 1. Correspondence map of the frequency of fast-food consumption by parents and children. Categories of frequency of consumption: 1 - daily, 2 - several times a week, 3 - once a week, 4 - sporadically

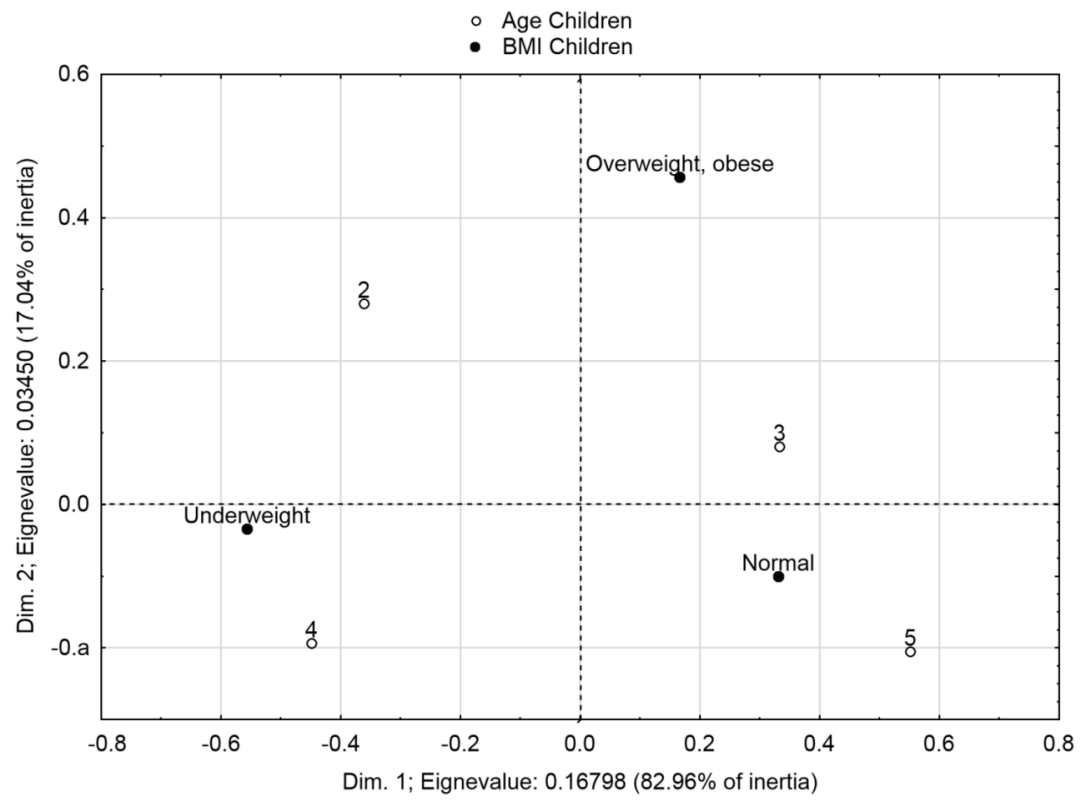

Figure 2. Correspondence map of the age of the first consumption of a fast-food product and the "child BMI" category. Age categories: $2(1 \leq$ age $<3), 3(3 \leq$ age $<4), 4(4 \leq$ age $<5), 5(5 \leq$ age $<6)$ 
Imaging of the Relationship Between Eating Habits of Parents...

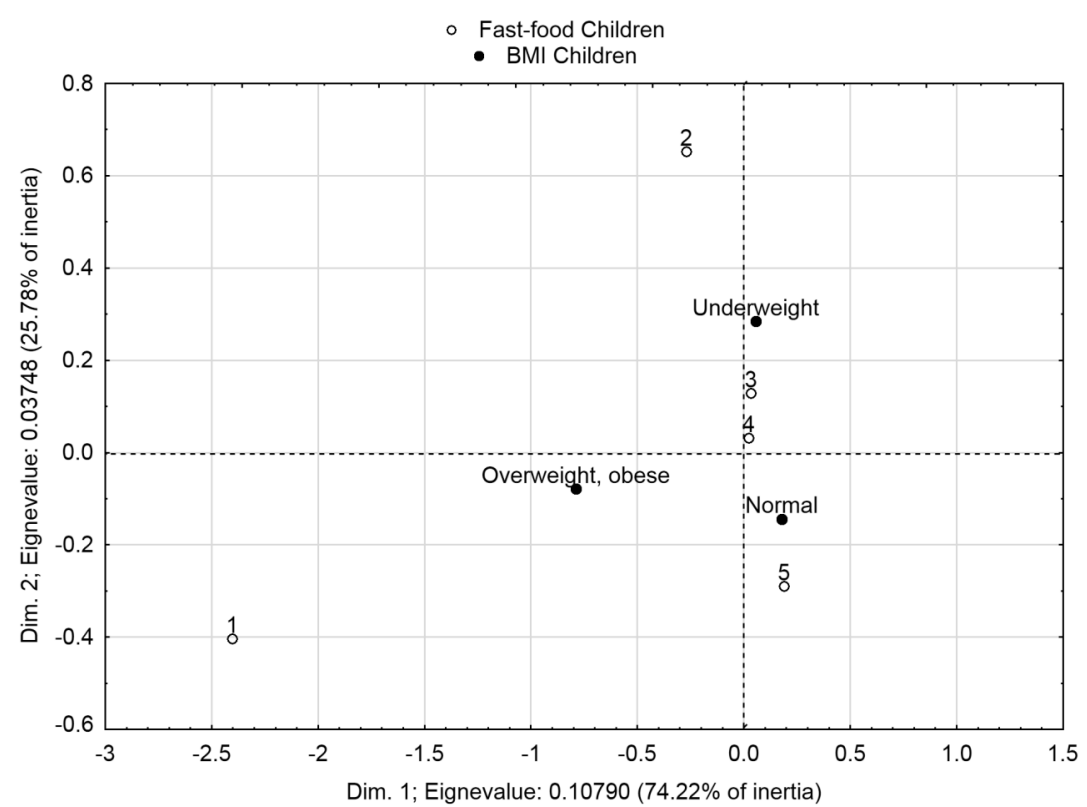

Figure 3. Correspondence map of the frequency of fast-food consumption and the "child BMI" category. Frequency of consumption: 1 - daily, 2 - several times a week, 3 - once a week, 4 - sporadically, 5 - never

existence of normal weight $(\mathrm{n}=37)$ and age category "5" (the upper-right section of the map); overweight and obesity $(\mathrm{n}=10)$ with age category " 3 " (the upper-right section of the map); and underweight $(\mathrm{n}=25)$ and age category "4" (the lower-left section of the map) can be observed. There exists a statistically significant relationship between the age groups and child BMI (chi-squared test, $\mathrm{p}=0.024$ ).

An analysis of the relationship between child BMI and the frequency of fast-food consumption is shown on the correspondence map - Figure 3. The map suggests that the children who had never eaten fast-foods were characterized by normal body weight (the lower-right section of the map); overweight and obese children consumed fast-foods daily (the lower-left section of the map), whereas underweight children ate such meals sporadically or once a week (the upper-right section of the map).

The most common reasons for the consumption of fast-foods reported by parents were: travel $(\mathrm{n}=67)$, lack of time $(\mathrm{n}=33)$, and shopping $(\mathrm{n}=25)$. The situation that statistically significantly contributed to frequent fastfood consumption by children, i.e. at least once a week (as compared with sporadic consumption), was children and parents shopping together $(\mathrm{p}<0.001)$ - Table 3 . 
Marta Stachurska et al.

Table 3. Situations conductive to fast-food consumption by children

\begin{tabular}{|c|c|c|c|c|}
\hline \multicolumn{2}{|c|}{ cause } & at least once a week & sporadically & p-value \\
\hline \multirow{2}{*}{ lack of time } & yes & $6(30.0 \%)$ & $27(25.7 \%)$ & \multirow{2}{*}{0.690} \\
\hline & no & $14(70.0 \%)$ & $78(74.3 \%)$ & \\
\hline \multirow{2}{*}{ shopping } & yes & $10(50.0 \%)$ & $15(14.3 \%)$ & \multirow{2}{*}{$<0.001$} \\
\hline & no & $10(50.0 \%)$ & $90(85.7 \%)$ & \\
\hline \multirow{2}{*}{ travel } & yes & $11(55.0 \%)$ & $56(53.3 \%)$ & \multirow{2}{*}{0.891} \\
\hline & no & $9(45.0 \%)$ & $49(46.7 \%)$ & \\
\hline \multirow{2}{*}{ requesting } & yes & $2(10.0 \%)$ & $7(6.7 \%)$ & \multirow{2}{*}{0.620} \\
\hline & no & $18(90.0 \%)$ & $97(93.3 \%)$ & \\
\hline \multirow{2}{*}{ another carer } & yes & $2(10.0 \%)$ & $9(8.6 \%)$ & \multirow{2}{*}{0.839} \\
\hline & no & $18(90.0 \%)$ & $96(91.4 \%)$ & \\
\hline \multirow{2}{*}{ other } & yes & $3(15.0 \%)$ & $18(17.1 \%)$ & \multirow{2}{*}{0.812} \\
\hline & no & $17(85.0 \%)$ & $87(82.9 \%)$ & \\
\hline
\end{tabular}

Fast-food type meals were consumed the most frequently in a restaurant $(59.8 \%)$, at home $(19.6 \%)$, or in a car $(13.1 \%)$. The products that were consumed by children the most often were chips (French fries) $(\mathrm{n}=118)$, pizza $(\mathrm{n}=95)$, and coated chicken $(\mathrm{n}=59)$. There is no statistically significant relationship between the type of the consumed fast-food and the frequency of its consumption - Table 4 .

Table 4. Types of fast-food products consumed by children

\begin{tabular}{|c|c|c|c|c|}
\hline \multicolumn{2}{|l|}{ fast-food } & at least once a week & sporadically & $\mathrm{p}$-value \\
\hline \multirow{2}{*}{ hamburger } & yes & $6(30.0 \%)$ & $32(30.5 \%)$ & \multirow{2}{*}{0.967} \\
\hline & no & $14(70.0 \%)$ & $73(69.5 \%)$ & \\
\hline \multirow{2}{*}{ chips (French fries) } & yes & $19(95.0 \%)$ & $99(94.3 \%)$ & \multirow{2}{*}{0.899} \\
\hline & no & $1(5.0 \%)$ & $6(5.7 \%)$ & \\
\hline \multirow{2}{*}{ hot-dog } & yes & $6(30.0 \%)$ & $27(25.7 \%)$ & \multirow{2}{*}{0.690} \\
\hline & no & $14(70.0 \%)$ & $78(74.3 \%)$ & \\
\hline \multirow{2}{*}{ pizza } & yes & $15(75.0 \%)$ & $80(76.2 \%)$ & \multirow{2}{*}{0.909} \\
\hline & no & $5(25.0 \%)$ & $25(23.8 \%)$ & \\
\hline \multirow{2}{*}{ coated chicken } & yes & $11(55.0 \%)$ & $48(45.7 \%)$ & \multirow{2}{*}{0.446} \\
\hline & no & $9(45.0 \%)$ & $57(54.3 \%)$ & \\
\hline \multirow{2}{*}{ cola } & yes & $11(55.0 \%)$ & $39(37.5 \%)$ & \multirow{2}{*}{0.144} \\
\hline & no & $9(45.0 \%)$ & $65(62.5 \%)$ & \\
\hline \multirow{2}{*}{ cocktails } & yes & $6(30.0 \%)$ & $24(22.9 \%)$ & \multirow{2}{*}{0.502} \\
\hline & no & $14(70.0 \%)$ & $81(77.1 \%)$ & \\
\hline
\end{tabular}


In most cases, the surveyed parents quoted harmful ingredients and diseases resulting from fast-food consumption correctly. Among those indicated the most frequently were obesity $(96.6 \%)$ and diabetes $(79.2 \%)$, whereas the harmful ingredients that they specified as those that occur the most often were fat (94.0\%) and sugar (88.6\%). The respondents were conscious of the risks of fast-food consumption and assessed such products as very harmful $(81.9 \%)$. They claimed that the media speak about them too infrequently (55.5\%). However, they did recognize the health education actions carried out among the surveyed preschool children (67.6\%). In addition, they stated that they admonish their relatives on refraining from serving their children unhealthy snacks (83.3\%). Most of the surveyed parents talk to their children about a healthy diet (89.0\%). It is worrying that only 12 out of $149(8.1 \%)$ of those surveyed provided the correct BMI formula.

\section{Discussion}

The parents that agreed to participate in the survey were mostly those with a higher level of education, with an average age of 35 years. Considering this, a relatively high awareness of the issue of the principles of a healthy diet of children and adults could be expected. The POL-MONICA study, conducted in Warsaw, showed that a higher level of education is connected with better nutritional behaviours (Waśkiewicz et al., 2000). However, in the authors' research, almost $85 \%$ of the parents declared that they served their children fast-foods. The children ate fast-foods for the first time at the average age of 3 years, the youngest one at an age as early as 1 year. Such an early introduction of foods of this type may have a significant impact on BMI values in children as well as, later on in their lives, on inappropriate dietary choices (Sosnowska-Bielicz \& Wrótniak, 2013). In the authors' research, there was a statistically significant relationship between the age of first fast-food consumption and child BMI. It can be suspected that late introduction of fast-foods is conductive to normal body weight.

Research conducted by Gacek (2012) among city children shows that almost $2 / 3$ of preschool children consumed fast-foods sporadically (or never). In the author's research, parents also declare that fast-food is consumed sporadically (almost $71 \%$ ).

In this study, most parents displayed correct knowledge about the harmful ingredients and diseases resulting from fast-food consumption. However, despite the high health awareness, they failed to be role models for 
their children as far as the principles of a healthy diet are concerned. Almost all parents of children that ate fast-foods admitted to consuming them in the child's presence. Moreover, coexistence of the same incidence of fast-food consumption by parents and children was noticed. In a study by $\mathrm{Hu}$ et al. (2010), performed in China, an impact of the conducted health education classes on the eating habits of children in four kindergartens was observed. It was discovered that after a cycle of classes, the parents' meal planning methods and product consumption patterns underwent significant changes for the healthier (Hu et al., 2010).

In the authors' research it was noticed that the situation conductive to frequent fast-food consumption by children, i.e. at least once a week (as compared with sporadic consumption), was children and parents shopping together. Moreover, parents indicated lack of time for home cooking and travelling together as the reasons for fast-food purchases. Such behaviour is caused by the increasing pace of life, with parents lacking the time for walks with their children or other healthy activities (SosnowskaBielicz \& Wrótniak, 2013).

The surveyed parents declared that fast-food meals were consumed the most frequently in restaurants. On the other hand, Stankiewicz et al. (2006), in their pilot study on diets of preschool children in the views of their parents, one-third of those surveyed stated that their children do not frequent fast-food type restaurants, whereas the rest declared that their children visit such places sporadically.

In the authors' research, the relationship between the frequency of fastfood consumption and child BMI was also analysed. The correspondence map shows, consistently with the widely observed trends, that children who had never eaten fast-foods were characterized by normal body weight, while overweight and obese children ate fast-foods daily.

Alviola et al. (2014), in their study conducted in Arkansas, proved that the availability of restaurants has an impact on children's body weight. In places where fast-food restaurants were located close to a highway, the results of body weight measurements were higher than in when restaurants were located at a greater distance from a main road. In addition, a similar relationship among children was proved as far as the distance between the fast-food restaurant and the school was concerned.

In the authors' research, no relationship between the type of the consumed fast-food and the frequency of consumption was observed. Among the products consumed the most frequently by children were chips (French fries), pizza, and coated chicken. Similar studies were conducted by Kośmider and Gronowska-Senger (2005), who showed that the fast-food chosen the most 
frequently by young people were crisps, chips (French fries), pizza, hot-dogs, and hamburgers.

\section{Conclusions}

The performed correspondence analysis enabled to observe numerous relationships between the eating habits of parents of preschool children and the patterns of fast-food consumption among their children. The vast majority of parents declared that they ate fast-food products in the presence of their children, which is why they were not good authorities for their children. Correspondence maps clearly showed that this translated into a similar frequency of consumption of such products both by parents and children. The presented correspondence maps also suggest that early introduction of fast-foods to the child's diet has an impact on the emergence of overweight and obesity in preschool children. Unfortunately, despite the high parent awareness of the harmfulness of fast-food products and the widespread health education, some children in kindergartens were overweight or even obese. For this reason, the quality of the educational programmes in kindergartens as well as in various media outlets needs to be improved, with emphasis put on their effectiveness, in order to minimise the problem of overweight and obesity in children. It is also important for parents rearing children to pay special attention not only to their children's menus, but also to what they themselves eat in the presence of their children.

\section{R E F E R E N C E S}

Alviola, P. A., Nayga, R. M., Thomsen, M. R., Danforth, D., \& Smartt, J. (2014). The effect of fast-food restaurants on childhood obesity: a school level analysis. Economics and Human Biology, 12, 110-119.

Centrum Zdrowia Dziecka. Siatki centylowe dzieci i młodzieży w wieku 3-18 lat. Retrieved from http://www.czd.pl/index.php?option=com_content\&view= article\&id $=1717 \&$ Itemid $=538$

Gacek, M. (2012). Sposób żywienia dzieci przedszkolnych ze środowiska wielkomiejskiego. Roczniki Państwowego Zaktadu Higieny, 63(4), 477-482.

Gheribi, E. (2014). Sieci franczyzowe w usługach gastronomicznych. Studia Ekonomiczne, 202, 160-169.

Greencare, M. J., \& Hastie, T. (1987). The geometric Interpretation of Correspondence Analysis. Journal of the American Statistical Association, 82(398), 437-447. 
Hu, Ch., Ye, D., Li, Y., Huang, Y., Li, L., Gao, Y., \& Wang, S. (2010). Evaluation of a kindergarten-based nutrition education intervention for pre-school children in China. Public Health Nutrition, 13(2), 253-260.

Jończyk, J. A., \& Olszewska, A. M. (2016). The use of correspondence analysis in assessing the antecedents of innovativeness in public hospitals. Studies in Logic, Grammar and Rhetoric. Logical, Statistical and Computer Methods in Medicine, 47(60), 85-101.

Kośmider, A., \& Gronowska-Senger, A. (2005). Postawa wobec żywności typu „Fast-food” i jej popularność wśród młodzieży szkolnej z rejonu Mazowsza. Roczniki PZH, 56(2), 139-148.

Kozioł-Kozakowska, A., Piórecka, B., Żwirska, J., Jagielski, P., \& Schegel-Zawadzka, M. (2007). Ocena sposobu żywienia dzieci w wieku przedszkolnym z regionu Krakowa z uwzględnieniem charakterystyki socjoekonomicznej. Problemy Higieny i Epidemiologii, 88(4), 422-427.

Kraak, V. I., \& Pelletier, D. L. (1998). How marketers reach young consumers: Implications for nutrition education and health promotion campaigns. Family Economics and Nutrition Review, 11, 31-41.

Łoś-Rycharska, E., \& Niecławska, A. (2010). Spożycie pokarmów typu fast-food przez dzieci w wieku poniemowlęcym i przedszkolnym. Pediatria Polska, 85(4), 345-352.

Marcysiak, M. (2009). Zachowania żywieniowe i aktywność fizyczna uczniów klas sportowych i ogólnych w Ustrzykach Dolnych. Problemy pielegniarstwa, $17(3), 217$.

Milewska, A. J., Jankowska, D., Górska, U., Milewski, R., \& Wołczyński, S. (2012). Graphical representation of the relationships between qualitative variables concerning the process of hospitalization in the gynecological ward using correspondence analysis. Studies in Logic, Grammar and Rhetoric. Logical, Statistical and Computer Methods in Medicine, 29(42), 7-25.

Rosenheck, R. (2008). Fast food consumption and increased caloric intake: a systematic review of a trajectory towards weight gain and obesity risk. Obesity Reviews, 9(6), 535-547.

Sosnowska-Bielicz, E., \& Wrótniak, J. (2013). Nawyki żywieniowe a otyłość dzieci w wieku przedszkolnym i szkolnym. Lubelski Rocznik Pedagogiczny, 32, 147165.

Stanimir, A. (2005). Analiza korespondencji jako narzędzie do badania zjawisk ekonomicznych. Wrocław: Wydawnictwo Akademii Ekonomicznej we Wrocławiu.

Stanimir, A. (2008). Wykorzystanie analizy korespondencji w badaniach marketingowych. In Zastosowanie metod statystycznych $w$ badaniach marketingowych III (pp. 337-346). Kraków: StatSoft Polska. 
Stankiewicz, M., Pęgiel-Kamrat, J., Zarzeczna-Baran, M., Jankowski, M., ŁysiakSzydłowska, W., \& Pieszko-Klejnowska, M. (2006). Styl żywienia dzieci przedszkolnych w opinii ich rodziców. Problemy Higieny i Epidemiologii, 87 (supl.), 119.

Waśkiewicz, A., Synowska, E., \& Szcześniewska, D. (2000). Wpływ poziomu wykształcenia na żywienie wybranych grup ludności w 10-letnim okresie obserwacji. Badanie POL-MONIKA Warszawa. Żywienie Człowieka i Metabolizm, 27(3), 219-237.

WHO, Country Office for Poland (2006). 10 faktów dotyczacych otyłości, o których należy wiedzieć. Paper presented at the WHO European Ministerial Conference on Counteracting Obesity, Diet and physical activity for health, Istanbul, Turkey. Retrieved from http://www.who.un.org.pl/aktualnosci.php? news $=92$

WHO (2017). Obesity and overweight. Retrieved from http://www.who.int/media centre/factsheets/fs311/en/ 